\title{
A REAL TIME MONITORING SYSTEM FOR ELECTRICAL OVERHEAD MONORAIL CONVEYOR
}

\author{
Marcus Vinícius Topázio Fernandes ${ }^{\mathrm{a}, \mathrm{b}}$, Oberdan Rocha Pinheiro ${ }^{a}$, Aloísio Santos \\ Nascimento Filho ${ }^{a}$ \\ a Senai CIMATEC, Brazil \\ b FORD Motor Company, Brazil
}

\begin{abstract}
In industrial factories, industry 4.0 concepts have been applied in predictive maintenance processes. Researches have shown that industry 4.0 concepts application may reduce timing and cost associated to equipment downtime. This study aims to identify characteristics to detect an imminent failure in an overhead monorail composed by a T6 6063 alloy. In this context, the challenge would be data acquisition and analysis to determine the correct technology to be applied to prevent a major breakdown. Based on that, the start point consisted in validate the used alloy proprieties to certify the material matching with current conveyor application. Preliminary efforts study has shown the used T6 alloy are running right at the yield limit, resulting in susceptible failure conditions. Further research is needed to identify other factors related to the effectiveness of the industry 4.0 in a real time monitoring of overhead conveyor to achieve a maintenance model to predict a failure event.
\end{abstract}

Keywords: Industry 4.0; Predictive Maintenance; Overhead Conveyor; Real-time monitoring

\section{SISTEMA DE MONITORAMENTO EM TEMPO REAL PARA TRANSPORTADOR ELÉTRICO DE TRILHO AÉREO}

Resumo: Em fábricas industriais, conceitos da indústria 4.0 têm sido aplicados em processos de manutenção preditiva. Pesquisas têm mostrado que a aplicação dos conceitos da indústria 4.0 pode reduzir o tempo e o custo associados ao tempo de parada de equipamentos. O presente estudo tem como objetivo identificar características para detectar uma falha iminente em um monotrilho aéreo composto por uma liga T6 6063. Nesse contexto, o desafio está na aquisição e análise de dados para determinar a tecnologia correta a ser aplicada para prevenir uma grande parada. Desse modo, o ponto de partida consistiu em validar as propriedades da liga utilizada a fim de certificar a compatibilidade do material com a aplicação atual do transportador. $\mathrm{O}$ estudo de esforços preliminares mostrou que a liga T6 está operando no limite de escoamento, resultando em condições suscetíveis a falhas. Pesquisas adicionais são necessárias para identificar outros fatores, relacionados à efetividade da indústria 4.0 no monitoramento em tempo real do transportador aéreo para desenvolver um modelo de manutenção para prever um evento de falha.

Palavras-chave: Industria 4.0; Manutenção Preditiva; Transportador Aéreo; Monitoramento em tempo real 


\section{INTRODUCTION}

In the current context of factories and industrial hubs, maintenance processes have expanded from "preventive" (to prevent) to "predictive" (to predict), which is one of the most recurring subjects in the industry extend. Predictive maintenance is about monitoring and inspection of machines in order to indicate their operating conditions [1]. With the development of technologies, it is possible to identify sources of potential failures, then take an action before the failure finally occur.

In this same context, the term Industry 4.0 has gained even more strength, being usually adopted in the production, distribution and commercial chains worldwide. The principle that guides this new concept is based on processes and machines connected in a network, as a collaborative community for the collection, exchange and analysis of data, in order to predict future behaviors and seek ideal solutions for possible problems [2].

The characteristics mentioned demonstrate a strong relationship between industry 4.0 and predictive maintenance procedures. In the industries, the maintenance of equipment is an aspect of great importance and affects the time of operation of the equipment and its efficiency. Therefore, equipment failures need to be identified and resolved, avoiding unexpected shutdown of production processes [2]. Didactically, using indicators related to the availability of an application, Mean Time Between Failures (MTBF) and Mean Time to Repair (MTTR) have great relevance in the performance analysis of processes.

To drive through the path for this evolution, this study intent to present an approach based on Industry 4.0 concepts to face an essential aspect in the factories: the evaluation of the health of critical assets/equipment. The study is based on the continuous monitoring of a monorail overhead conveyor and the integrity of the process related to it, allowing maintenance to be performed only when necessary. In addition, early detection of failures is sought with the use of tools based on historical data (such as machine learning techniques), integrity factors (visual aspects, wear, different color from the original), statistical inference methods and engineering [3].

In a mass production line, ensure continuous flow is essential for the plant to achieve an increasingly efficient operation. To accomplish these results and minimize unexpected interruptions, high equipment availability and reliability must be achieved.

\subsection{ELECTRICAL OVERHEAD MONORAIL CONVEYOR}

Electrical Overhead Monorail (EOM) systems as illustrated in the Figure 1 are indicated for mass production processes in series, where there is a need to move unit loads that require a high degree of flexibility, combined with the facilities to synchronize speeds with other production processes. EOM conveyors are equipped with electronic control boxes with dedicated Programmable Logic Controller (PLC) and control via WiFi which allows the combination of horizontal and vertical movements and flexible layouts. 
Figure 1. Overhead conveyor in an automotive assembly line

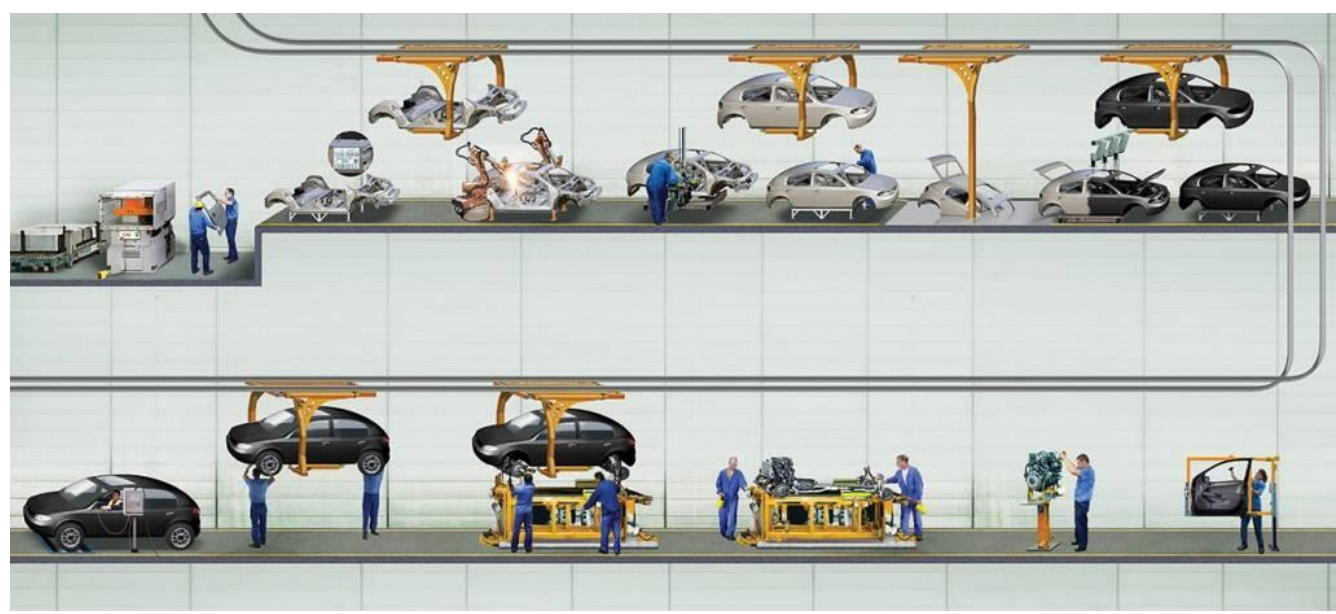

Source: Extracted from [2]

Considered as a critical asset in an assembly line of an automobile factory, this system is responsible for the transport of the vehicle bodies. The rail structure of the conveyor that will be the object of study has as raw material the alloy composed of Al$\mathrm{Mg}-\mathrm{Si}$, commercially known as 6xxx alloy series.

The alloy used in the present study is from the 6063 family, often used in electrical applications in the conditions of tempera T4, T5 and T6, due to its good electrical conductivity. Tempera consists in a process to achieve mechanical resistance properties by heating the part to a high temperature and then suddenly cooling it down [4]. For this specific conveyor rail application, it is presented as T6 temper.

Over the years of operation, some events of interruption of the operation due to failures caused by cracks and breaks in the rail have already been faced, generating losses in the order of millions of reals. There are few different events such as illustrated in the Figure $2 \mathrm{a}$ on the bifurcation track trail, in the Figure $2 \mathrm{~b}$ on the straight section and through Figure $2 \mathrm{c}$ in the curve section.

Figure 2. Different ruptures in the conveyor rail (a. Bifurcation track trail, b. Straight Section, c. Curve Section)

a)

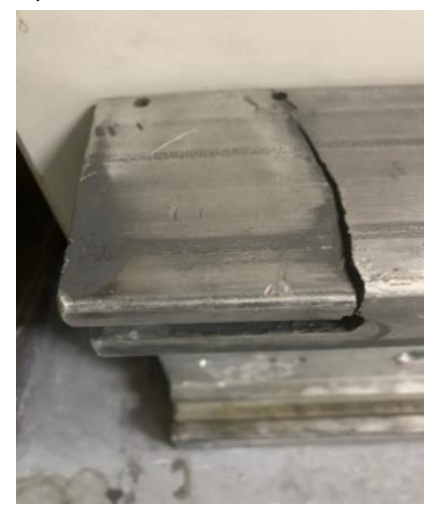

b)

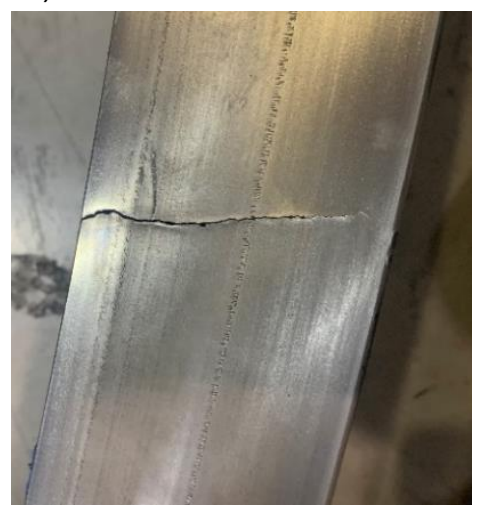

Source: Author c)

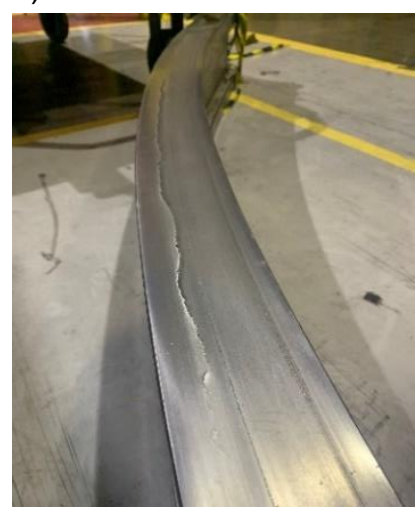


The average time of interruption in the production process, to carry out corrective maintenance on the EOM tracks, after its interruption, is roughly 4 hours. Showing evidences of the importance of predictive detection of potential failure modes, before they actually occur.

Having this equipment in failure / stopped, the production line goes down and the company stops generating value. In addition, having to deal with a downtime on the production line is making a series of important decisions in a short time, which can jeopardize the workflow of the entire plant. Therefore, companies have increasingly invested in the development of strategies to minimize these cases.

In the search for these strategies, the present study seeks to define a plan for monitoring the track of a conveyor of an automobile factory in Bahia, in order to identify characteristics that indicate imminent failures, such as cracks, unevenness and/or ruptures. After identifying these characteristics, an inspection and predictive maintenance plan will be defined whenever a possible discontinuity in the system is signaled.

\section{METHODOLOGY}

For the development of the present study it is necessary to deep dive the used alloy material in order to determine the root cause of the failures. By understanding the reasons of the failures, it might help to determine the correct monitoring strategy for this specific application.

The proposal was to start with a load distribution study of the carriers loaded with the different vehicle models to ensure the mechanical efforts are not out of the yield limits for the used alloy material.

The 6063 T6 alloy deep dive is also required to determine the mechanical proprieties of the material which will be compared later with the load distribution data results. It implies in several data acquisition and simulation studies to validate that current system is robust enough. This also aims to identify characteristics that indicate a tendency for imminent failure on the conveyor track rail which will help to determine the correct monitoring strategy.

In parallel, the search for available technologies are necessary to stablish a reliable system to monitor the rail in real time that will look for the characteristics identified before the failure finally occurs to match with the appropriated technology with a reasonable cost and maintainability.

The intent is to analyze the previously experienced cases with the performed studies mentioned above with the objective of verifying the propositions and outline the conclusion which will drive to answer if the proposed system strategy will be able to catch them in advanced with the objective of ensuring that the chosen methodology has validity and reliability.

In fact, the case study proposed to identify a problem, analyze the evidence, develop logical arguments, evaluate and propose solutions. This method is even more relevant when the phenomenon to be studied is broad and complex and cannot be studied outside the context where it occurs naturally. 


\section{RESULTS AND DISCUSSION}

In a line stoppage caused by failure or breakage of some equipment, the industry is obliged to stop production in order to carry out the maintenance of this machine. The total time for this type of stop includes discovering the problem, communicating to the maintenance team, the interval required for the team to arrive at the location, and then repair the equipment, validate the interim or permanent containment action and return to operation time.

With the perspective of Industry 4.0, which presents predictive maintenance as a tool, it is expected from the present work, to define a continuous monitoring plan on the conveyor tracks, identifying patterns of behavior, and, through them, define actions before problems will happen. It is expected, therefore, to reduce the time necessary to carry out repairs to the overhead conveyor rail, once it can be programmed, thus eliminating unexpected interruptions in the production process [5].

The expectation is to reduce the absolute value of the MTTR, in order to reduce the repair time, due to the fact that the correction is made in a planned and nonemergency way, due to prior knowledge of the cause of the problem and what action must be taken to correct it, as well as an increase in MTBF, making interference and stops in the equipment increasingly spaced.

Preliminary studies were conducted to analyze current EOM application showing it is already running right at the yield limit $(160 \mathrm{MPa})$ in many points for the used $6063 \mathrm{~T} 6$ alloy. Some of the points are going even higher reaching up to $240 \mathrm{MPa}$, as shown in the Figure 3. It means that the used rail has been submitted to an intense stress all over its life cycle, resulting in the cracks and downtimes mentioned previously.

Figure 3. CAE simulation result for the current T6 rail alloy. Yield limits are demonstrated through the color scale in MPa.
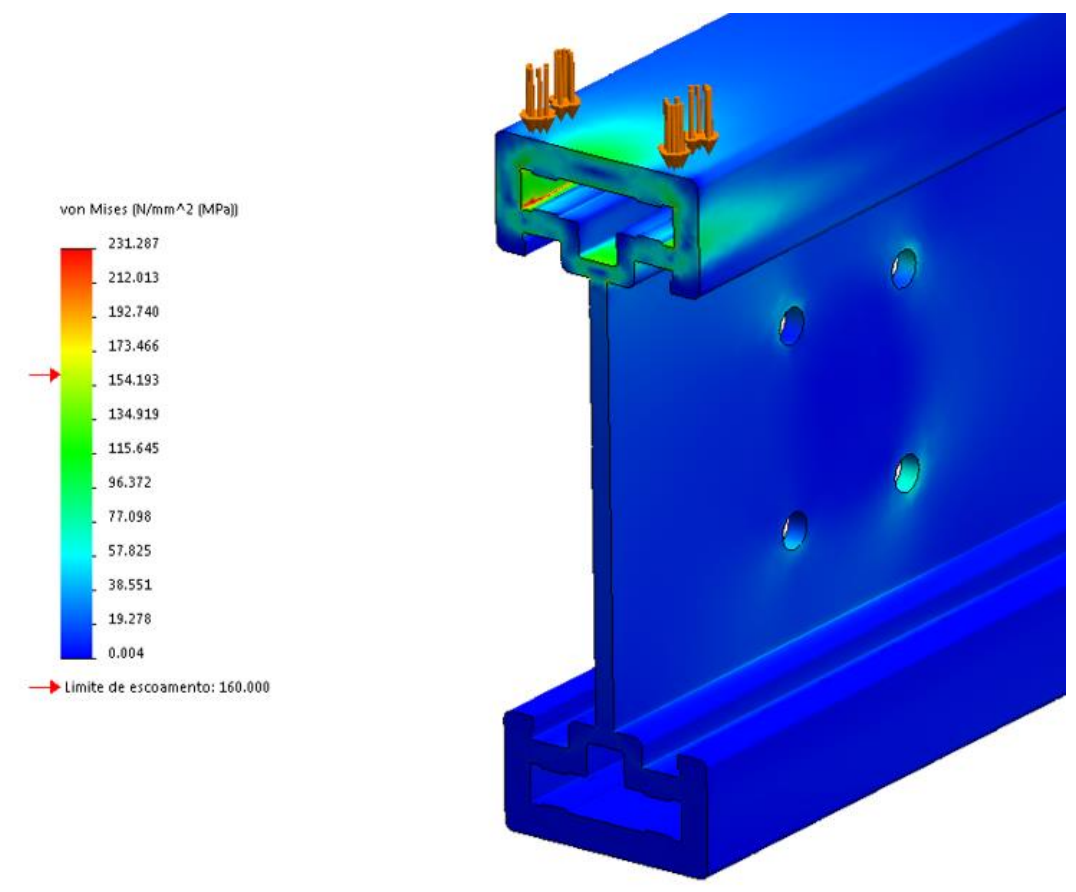

Source: Author 
The alloy 6063 mechanical limits data presented in the Table 1 [4] for few of the different temperas validates the CAE study performed as previously shown in the Figure 3 which indicate potential rupture due to efforts overachieving the yield limit of $160 \mathrm{MPa}$.

Table 1. Alloy 6063 - Mechanical Limits

\begin{tabular}{|c|c|c|c|c|c|}
\hline \multirow{2}{*}{ Tempera } & \multirow{2}{*}{$\begin{array}{l}\text { Specific Section or } \\
\text { thickness } \\
(\mathbf{m m})\end{array}$} & \multicolumn{2}{|c|}{$\begin{array}{l}\text { Stress Resistence } \\
\text { Limit (MPa) }\end{array}$} & \multicolumn{2}{|c|}{$\begin{array}{l}\text { Yield Limit } \\
\quad(\mathrm{MPa})\end{array}$} \\
\hline & & Min & Max. & Min. & Max. \\
\hline 0 & ALL & - & 130 & - & - \\
\hline \multirow{2}{*}{ T4 } & Up to 12.5 & 130 & - & 70 & - \\
\hline & $12.5-25.00$ & 125 & - & 60 & - \\
\hline \multirow{2}{*}{ T5 } & Up to 12.5 & 175 & - & 130 & - \\
\hline & $12.5-25.00$ & 160 & - & 110 & - \\
\hline \multirow{2}{*}{ T6 } & Up to 3.20 & 215 & - & 170 & - \\
\hline & $3.20-25.00$ & 195 & - & 160 & - \\
\hline
\end{tabular}

Source: Extracted from [4]

Therefore, before defining the way of monitoring the rail in real time, it is required to determine a better alloy material that supports the EOM application and the vehicle bodies carried out. A proposed system architecture has been discussed with plant maintenance and upper management teams to state the requirements of the system and these outcomes are illustrated in the Figure 4.

Figure 4. Real-Time Monitoring System Proposed Architecture

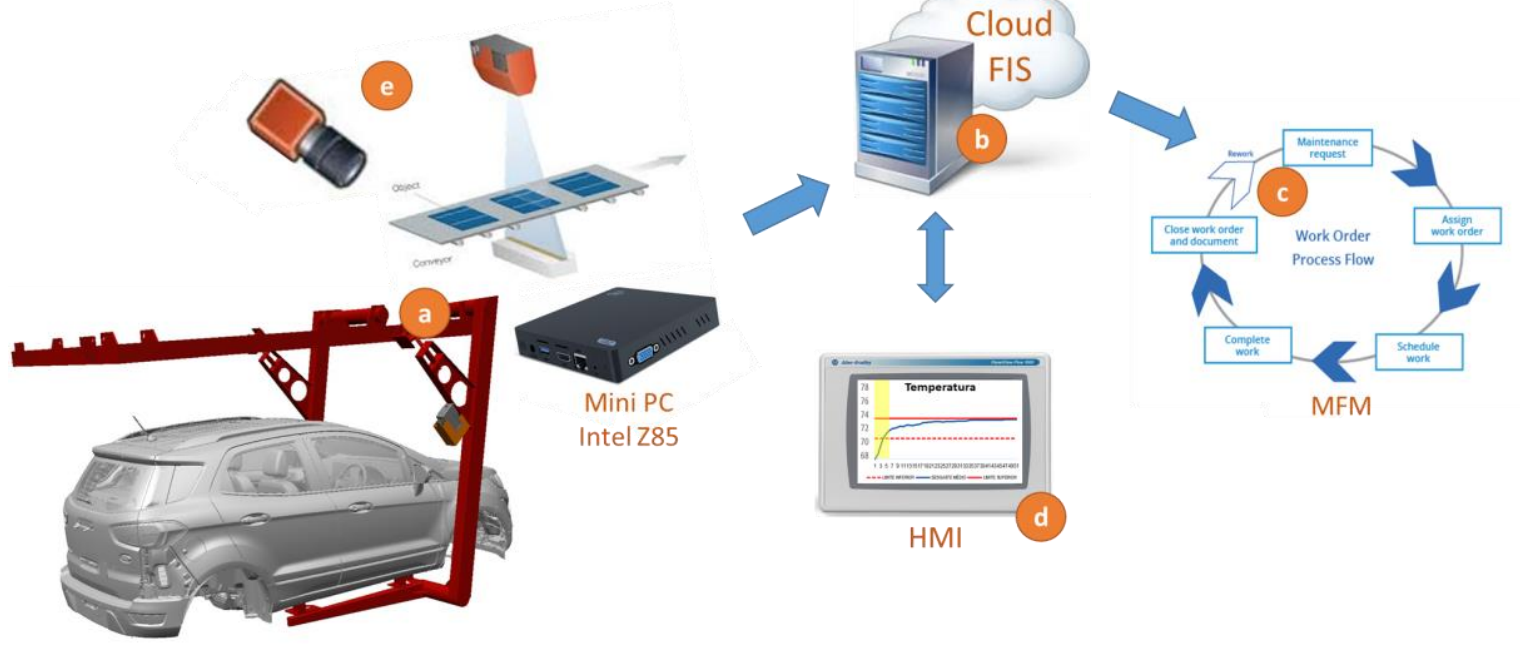

Source: Author 
Basically, the system has to run attached in one of the 60 used carriers (Figure 4a) to monitor the whole 160 meters of the EOM rail and should communicate with the plant cloud computing system (Figure 4b). Acquired data will be compared with the previously learned data to determine if there are any potential failure identified.

In case of an imminent failure is identified by processing the acquired data, the cloud computing system will take an action by opening a service order (Figure 4c) into the Maximo For Maintenance (MFM) which is the maintenance scheduling management system for all the predictive, preventive, corrective and autonomous maintenances plans without the need of a human intervention [6].

The maintenance crew will be able to take a look into it once and every time it is required since it will show in real time the monitoring data at the Human Machine Interface (HMI - Figure 4d) which consists in few systems screens for monitoring purposes.

Considering the assembly line speed of $47 \mathrm{JPH}$ (Jobs Per Hour), the system will be completely verified in each 90 minutes, resulting in about 15 full verifications per day, considering 3 shifts of operation.

The challenge in this proposed system architecture is to define the best technology to read/identify the imminent failure event by either using high definition cameras, x-ray, thermo cameras or any other technology (Figure 4e).

\section{CONCLUSION}

Regarding the general objective of this project which is to define a predictive maintenance plan for the monorail overhead conveyor system, the analysis of the new alloy material as well as the monitoring system are crucial important for the creation of the plan.

Among the variables that affect / damage the overhead conveyor rails, it has been observed that the definition of the alloy material composition stands out as the most relevant. Other variables other than the alloy material will be evaluated during the project development and their relevance will be highlighted.

The characteristics that indicate a tendency for imminent failure in the conveyor track are key for the success of this project and it is object of the next phases of the present project, as well as the definition of the monitoring technology for the overhead conveyor system.

The study carried out so far confirms the importance of the theme, demonstrating that the implementation of interconnected maintenance systems can optimize the use of the equipment, as well as a robust definition of the components of this system, guarantee a longer useful cycle life.

Further studies might be performed in order to determine the flawless alloy material to the overhead conveyor application in this project. Once it is settled then effort tests might be carried out to determine the characteristics to be verified by the monitoring system. And finally, develop, validate and implement the real-time monitoring system which is the main goal of this project. 


\section{REFERENCES}

${ }^{1}$ WAN, J., TANG, S., LI, D., WANG, S., LIU, C., ABBAS, H., \& Vasilakos, A. V. A manufacturing big data solution for active preventive maintenance. IEEE Transactions on Industrial Informatics. Volume 13. P. 99. Fevereiro, 2017.

${ }^{2}$ CARVALHO, I. Como funciona uma linha de montagem de automóveis? São Paulo, 2017. Disponível em: <https://quatrorodas.abril.com.br/noticias/como-funcionauma-linha-de-montagem-de-automoveis/> Acesso em 26 dez. 2019.

${ }^{3}$ CARVALHO, T. P.; SOARES, F. A. A. M. N.; VITA, R.; FRANCISCO, R. P. ; BASTO, J.P.; ALCALÁ, S.G.S. A systematic literature review of machine learning methods applied to predictive maintenance. Computers \& Industrial Engineering. Volume 137. Novembro, 2019.

${ }^{4}$ SILVA, J. C. P. Avaliação do comportamento das ligas de alumínio 6005, 6063, 6351 submetidas a diferentes tratamentos térmicos. Instituto Federal de educação, ciência e tecnologia de Goiás. Goiânia. 2015.

${ }^{5}$ LASI, H., FETTKE, P., KEMPER, H.-G., FELD, T., HOFFMAN, M., 2014. Industry 4.0. Business \& Information Systems Engineering. Volume 6. P. 239-242. Agosto, 2014.

${ }^{6}$ KANG, H.S.; LEE, J. Y.; CHOI, S.; KIM, H.; PARK, J.H.; SON, J. Y.; KIM, B. H.; NOH, S. D.I. Smart manufacturing: Past research, present findings, and future directions. International Journal of Precision Engineering and Manufacturing-Green Technology. Volume 3. P. 111-128. Janeiro, 2016. 